Artikel Penelitian

\title{
Identifikasi dan Uji Toksisitas terhadap Larva Udang (Artemia salina L.) Ekstrak Bekatul Menggunakan Variasi Jenis Pelarut dan Lama Ekstraksi
}

\author{
Dewi Wardatul Jannah, Anik Maunatin, Akyunul Jannah*
}

Jurusan Kimia, Fakultas Sains dan Teknologi, Universitas Islam Negeri Maulana Malik Ibrahim, Malang, Indonesia, 65144

\section{INFO ARTIKEL}

\section{Riwayat Artikel}

Diterima 15 September 2020

Direvisi 20 Desember 2020

Tersedia online 25 Januari 2021

*Email penulis korespondensi:
akyunul_jannah2008@yahoo.com

\section{ABSTRAK}

Rice bran was extracted using ultrasonic method with varied solvents (ethanol, ethyl acetate and n-hexane) and extraction times (20,25 and 30 minutes). The aim of this study was to determine toxicity value of rice bran extract with variation of solvents and extraction times. Rice bran extracts were tested its toxicity by BSLT method and its secondary metabolite by phytochemical test with reagents. Mortality data of shrimp larvae was analyzed by probit to determine $L_{50}$ values. Yield of ethanolic extract of rice bran for E1-20, E1-25 and E1-30 samples was $18.159,19.132$ and $18.280 \%$, respectively. Rice bran extracts by ethyl acetate solvent (E2) and $n$-hexane (E3) gave different yields such as $8.302 \%$ (E2-20), $7.282 \%$ (E2-25), 9.18\% (E2-30), 7.815\% (E3-20), 7.125\% (E3-25), and $7.279 \%$ (E3-30). All of rice bran extracts contained flavonoids, steroids and triterpenoids. $\mathrm{LC}_{50}$ values in ethanolic extract of rice bran for E1-20, E1-25 dan E1-30 samples were $613.258,673.210$ and $2217.255 \mathrm{ppm}$, respectively. Toxicity $\left(\mathrm{LC}_{50}\right)$ values of ethyl acetate extract of rice bran were 1161.298 ppm (E2-20), 1170.774 ppm (E2$25)$ and $701.532 \mathrm{ppm}(\mathrm{E} 2-30)$, while toxicity ( $\left.\mathrm{LC}_{50}\right)$ values of $\mathrm{n}$-hexane extract of rice bran were 592.901 ppm (E3-20), 617.425 ppm (E3-25) and 695.198 ppm (E330).

Keywords: Rice bran, secondary metabolite, toxicity, ultrasonic method

Bekatul diekstrak menggunakan metode ultrasonik dengan variasi pelarut (etanol, etil asetat dan $n$-heksana) dan lama ekstraksi (20, 25 dan 30 menit). Tujuan penelitian ini adalah mengetahui nilai toksisitas ekstrak bekatul dengan variasi pelarut dan lama ekstraksi. Ekstrak bekatul diuji kemampuan toksisitas terhadap larva udang dengan metode BSLT dan diuji fitokimia dengan reagen. Data kematian larva udang dianalisis dengan analisis probit untuk menentukan nilai $\mathrm{LC}_{50}$. Rendemen ekstrak etanol bekatul yang diperoleh pada sampel E1-20, E1-25 dan E1-30 masing-masing sebesar 18,159; 19,132; dan 18,280\%. Adapun rendemen ekstrak etil asetat dan n-heksana bekatul sebesar 8,302\% (E2-20), 7,282\% (E2-25), 9,18\% (E2-30), 7,815\% (E3-20), 7,125\% (E3-25) dan 7,279\% (E3-30). Senyawa metabolit sekunder yang terkandung pada masing-masing ekstrak adalah flavonoid, steroid dan triterpenoid. Nilai $\mathrm{LC}_{50}$ ekstrak etanol pada masing-masing sampel E1-20, E1-25 dan E1-30 adalah 613,258; 673,210 dan 2217,255 ppm. Ekstrak etil asetat bekatul pada sampel E2-20, E2-25 dan E2-30 memberikan nilai toksisitas dengan $\mathrm{LC}_{50}$ sebesar 1161,398; 1170,774 dan $701,532 \mathrm{ppm}$, berturut-turut. Nilai toksisitas ( LC $\left._{50}\right)$ ekstrak n-heksana pada sampel E3-20, E3-25 dan E3-30 adalah 592,901; 617,425 dan 695,198 ppm, berturut-turut.

Kata kunci: Bekatul, metabolit sekunder, toksisitas, metode ultrasonik 


\section{Pendahuluan}

Bekatul adalah hasil samping dari pengolahan padi yang umumnya digunakan untuk makanan ternak. Bekatul yang dihasilkan dari penggilingan padi dapat mencapai 8-12\% dari jumlah total padi. Hasil sampingan lainnya adalah 15-20\% sekam yang merupakan kulit terluar dan 3\% menir [1]. Bekatul mangandung komponen bioaktif atau senyawa fitokimia yang tinggi seperti tokoferol, tokotrienol, $\boldsymbol{\gamma}$-oryzanol [2], asam fenolat [3] dan karotenoid [4]. Hasil pengujian fitokimia ekstrak bekatul menghasilkan senyawa fenolik, flavonoid, triterpenoid, alkanoid dan saponin menggunakan pelarut butanol, etil asetat dan n-heksana [5].

Pemilihan metode ekstraksi penting dilakukan karena hasil ekstraksi dapat mencerminkan tingkat keberhasilan metode yang digunakan [6]. Metode maserasi merupakan metode yang umum digunakan untuk mengekstrak senyawa aktif dari bahan alam termasuk sampel bekatul. Salah satu parameter keberhasilan ekstraksi adalah persentase rendemen. Nilai rendemen dipengaruhi oleh jenis pelarut yang digunakan. Widarta dkk. [7] mengekstrak bekatul beras lokal dengan metode maserasi menghasilkan rendemen $8,37-9,99 \%$ dengan pelarut etanol. Ekstraksi bekatul beras ketan hitam memberikan rendemen masing-masing sebesar $7.9 \%$ dan $9.5 \%$ dengan campuran pelarut $n$-heksana dengan metanol dan kloroform dengan metanol [8].

Optimasi ekstraksi bekatul dapat dilakukan dengan metode ultrasonik. Metode ini memanfaatkan gelombang akustik untuk memecah dinding sel [6]. Penelitian yang dilakukan oleh Dewi [9] adalah mengekstrak bekatul dan mendapatkan rendemen sebesar $18,32 \%$ dengan pelarut $n$-heksana menggunakan metode ultrasonik. Penelitian tersebut menunjukkan bahwa metode ultrasonik memiliki kemampuan untuk mengekstrak bekatul lebih baik dibandingkan dengan maserasi. Pengunaan metode ultrasonik dalam ekstraksi bekatul pada penelitian ini diharapkan dapat meningkat nilai rendemen yang diperoleh.

Aplikasi pemanfaatan ekstrak bekatul di bidang kesehatan cukup luas. Ekstrak minyak bekatul dapat berfungsi sebagai antioksidan [10] dan antikanker [11]. Pengujian awal terhadap ekstrak bekatul dilakukan dengan Metode Brine Shrimp Lethality Test (BSLT). Metode ini umum digunakan untuk menguji aktivitas suatu senyawa menggunakan hewan uji berupa larva udang Artemia salina L. [12]. Tujuan penelitian ini untuk mengetahui pengaruh variasi pelarut dan lama ekstrak bekatul pada larva udang dan mengidentifikasi senyawa metabolit sekunder yang terkandung dalam ekstrak bekatul.

\section{Bahan dan Metode}

\subsection{Bahan}

Bekatul yang digunakan berasal dari beras putih varietas Pertiwi di Desa Ketetang, Bangkalan. Pelarut yang digunakan untuk proses ekstraksi adalah etanol $96 \%$, etil asetat, dan n-heksana. Bahan yang digunakan untuk uji toksisitas adalah dimetil sulfoksida (DMSO), ragi roti, air laut, dan larva udang (Artemia salina L.). Bahan kimia lain yang diperlukan adalah reagen Dragendroff, reagen Meyer, asam klorida $2 \%$, metanol $50 \%$, serbuk $\mathrm{Mg}$, asam klorida pekat, kloroform, asam asetat anhidrat, asam sulfat pekat, asam klorida $1 \mathrm{~N}, \mathrm{FeCl}_{3} 1 \%$ dan plat silika gel $\mathrm{F}_{254}$.

\subsection{Persiapan Sampel}

Bekatul hasil penggilingan padi sebanyak $100 \mathrm{~g}$ dibersihkan dan diayak dengan ukuran 40 mesh. Bekatul yang sudah seragam ukurannya ditentukan kadar air berdasarkan prosedur AOAC [13].

\subsection{Ekstraksi dengan Metode Ultrasonik}

Lima gram bekatul dimasukkan dalam erlenmeyer berbeda yang sudah dilabel. Kemudian, masing-masing erlenmeyer dimasukkan $50 \mathrm{~mL}$ pelarut etanol, etil asetat dan $\mathrm{n}$-heksana atau dengan perbandingan sampel:pelarut sebanyak 1:10. Sampel dimasukkan dalam ultrasonic bath dengan frekuensi $20 \mathrm{kHz}$ pada suhu kamar. Variasi waktu yang digunakan adalah 20, 25 dan 30 menit. Ekstrak bekatul disaring dan filtrat yang diperoleh dievaporasi menggunakan rotary vacuum evaporator pada suhu $60^{\circ} \mathrm{C}$ dan dihitung rendemennya [14]. Total sampel ekstrak bekatul berjumlah 9 yang diberi kode E1-20, E1-25, dan E1-30 untuk pelarut etanol, E2-20, E2-25, E-30 untuk pelarut etil asetat dan E3-20, E3-25, E3-30 untuk pelarut n-heksana.

\subsection{Uji Toksisitas terhadap Larva Udang}

Ekstrak bekatul sebanyak $100 \mathrm{mg}$ dilarutkan menggunakan tiga pelarut berbeda (etanol, etil asetat, dan $\mathrm{n}$-heksana) sebanyak $10 \mathrm{~mL}$. Larutan tersebut diambil sebanyak 1000, 500, 200, 100, 50, dan $25 \mu \mathrm{L}$, kemudian dimasukkan ke dalam botol vial dan pelarutnya diuapkan hingga kering. Selanjutnya, ekstrak kering sampel ditambah $100 \mu \mathrm{L}$ DMSO, setetes larutan ragi roti, dan $2 \mathrm{~mL}$ air laut. Campuran dikocok sampai ekstrak dapat larut dalam air laut dan dipindahkan ke dalam labu ukur $10 \mathrm{~mL}$ dan dimasukkan 10 ekor larva udang. Larutan tersebut ditandabataskan dengan air laut 
sampai volumenya menjadi $10 \mathrm{~mL}$. Konsentrasi akhir masing-masing larutan menjadi 1000, 500, 200, 100, 50, dan 25 ppm.

Kontrol digunakan sebagai pembanding dibuat dengan cara yang sama dengan prosedur diatas akan tetapi tanpa penambahan ekstrak. Pengamatan dilakukan selama 24 jam terhadap kematian larva udang. Perhitungan $\mathrm{LC}_{50}$ dilakukan menggunakan analisis probit menggunakan SPSS 20 dengan tingkat kepercayaan 95\% [15].

\subsection{Uji Fitokimia pada Ekstrak Bekatul}

\subsubsection{Alkaloid}

Ekstrak kasar bekatul dimasukkan dalam tabung reaksi sebanyak $1 \mathrm{mg}$ dan ditambah $0,5 \mathrm{~mL}$ asam klorida $2 \%$. Campuran tersebut dibagi dalam dua tabung dimana tabung I ditambahkan 2-3 tetes reagen Dragendorff dan tabung II ditambahkan 2-3 tetes reagen Meyer. Apabila pada tabung I terbentuk endapan jingga dan pada tabung II terbentuk endapan kekuning-kuningan maka sampel mengandung alkaloid [16].

\subsubsection{Flavonoid}

Ekstrak kasar bekatul dimasukkan dalam tabung reaksi sebanyak $1 \mathrm{mg}$ dan dilarutkan dalam 1-2 $\mathrm{mL}$ metanol panas $50 \%$. Setelah itu, ditambah serbuk Mg dan 4-5 tetes asam klorida pekat. Larutan berwarna merah atau jingga yang terbentuk menunjukkan adanya flavonoid [16].

\subsubsection{Triterpenoid dan Steroid}

Ekstrak kasar bekatul dimasukkan dalam tabung reaksi sebanyak $1 \mathrm{mg}$ dan dilarutkan dalam $0,5 \mathrm{~mL}$ kloroform, lalu ditambah dengan $0,5 \mathrm{~mL}$ asam asetat anhidrat. Campuran ini selanjutnya ditambah dengan 1-2 $\mathrm{mL}$ asam sulfat pekat melalui dinding tabung tersebut. Cincin kecoklatan atau violet pada perbatasan dua pelarut menunjukkan adanya triterpenoid, sedangkan terbentuknya warna hijau kebiruan menunjukkan adanya steroid [16].

\subsubsection{Saponin}

Ekstrak kasar bekatul dimasukkan ke dalam tabung reaksi sebanyak $1 \mathrm{mg}$ dan ditambah air (1:1) sambil dikocok selama 1 menit. Apabila menimbulkan busa ketika ditambahkan asam klorida $1 \mathrm{~N}$ dan busa yang terbentuk dapat bertahan selama 10 menit dengan ketinggian 1-3 cm maka ekstrak positif mengandung saponin [16].

\subsubsection{Tanin}

Ekstrak kasar bekatul masukkan ke dalam tabung reaksi sebanyak $1 \mathrm{mg}$ dan ditambahkan dengan 2-3 tetes larutan $\mathrm{FeCl}_{3} 1 \%$. Jika larutan menghasilkan warna hijau kehitaman atau biru tinta maka ekstrak bekatul tersebut mengandung $\operatorname{tanin}[16]$.

\subsection{Pemisahan Senyawa Aktif dengan Kromatografi Lapis Tipis Analitik (KLTA)}

Pemisahan dengan KLTA dilakukan terhadap golongan senyawa yang positif terhadap uji fitokimia dan memiliki nilai $\mathrm{LC}_{50}$ paling rendah berdasarkan uji toksisitas. Pemisahan dilakukan dengan plat silika gel $\mathrm{F}_{254}$ yang sudah diaktifkan dengan pemanasan pada suhu $100^{\circ} \mathrm{C}$ selama 30 menit. Masing-masing plat memiliki ukuran $1 \times 10 \mathrm{~cm}$. Ekstrak bekatul ditotolkan sebanyak 10 kali pada jarak $1 \mathrm{~cm}$ dari tepi bawah plat dengan pipa kapiler. Kemudian, plat diletakkan dalam chamber yang sudah berisi eluen campuran etil asetat dan $n$-heksana (2:8) yang sudah dijenuhkan selama 1 jam. Noda hasil pemisahan diamati di bawah sinar UV pada panjang gelombang $366 \mathrm{~nm}$ [17].

\subsection{Pemisahan Senyawa Aktif dengan Kromatografi Lapis Tipis Preparatif (KLTP)}

Pemisahan dengan KLTP menggunakan plat silika gel $F_{254}$ dengan ukuran $10 \times 20 \mathrm{~cm}$. Ekstrak bekatul ditotolkan sepanjang plat pada jarak $1 \mathrm{~cm}$ dari garis bawah. Selanjutnya, plat dikeringanginkan dan ekstrak ditotolkan kembali hingga 10 kali penotolan. Eluen yang digunakan adalah campuran etik asetat:n-heksana dengan komposisi 2:8. Elusi dihentikan ketika eluen sampai pada garis batas. Plat hasil elusi dikeringkan dan noda yang terbentuk diamati dengan lampu UV pada panjang gelombang 366 dan $254 \mathrm{~nm}$ serta dihitung nilai $R f$-nya [17].

\section{Hasil dan Pembahasan}

\subsection{Persiapan Sampel}

Pada penelitian ini menggunakan bekatul beras putih dengan ukuran 40 mesh. Penyeragaman ukuran bertujuan untuk mempermudah kelarutan komponen bioaktif. Adapun kadar air pada sampel bekatul sebesar 8,069\% (b/b). Kadar air tersebut cukup baik untuk dilakukan proses ekstraksi secara maksimal dan dapat disimpan dalam jangka waktu yang cukup panjang. Kadar air yang kurang dari $10 \%$ (b/b) dapat menghentikan reaksi enzimatis yang dapat menguraikan 
senyawa aktif [18]. Semakin kecil kadar air suatu sampel, maka semakin mudah pelarut untuk mengekstrak komponen senyawa aktif, sehingga akan diperoleh rendemen semakin besar [19].

\subsection{Ekstraksi Bekatul}

Ekstraksi dilakukan menggunakan metode ultrasonik dengan pelarut etanol, etil asetat dan n-heksana dengan lama ekstraksi yaitu 20, 25 dan 30 menit. Ketiga pelarut memiliki sifat kepolaran yang berbeda-beda dengan variasi lama ekstraksi yang bertujuan untuk mengoptimalkan hasil ekstraksi. Hasil rendemen ekstraksi ultrasonik ditunjukkan pada Tabel 1.

Berdasarkan Tabel 1, nilai rendemen yang diperoleh bervariasi bergantung jenis pelarut dan lama ekstraksi. Hasil penelitian menunjukkan nilai rendemen tertinggi pada ekstrak bekatul diperoleh dengan pelarut etanol yaitu sebesar 18,159-19,132\%. Hal ini mengindikasikan bahwa senyawa yang ada pada pada ekstrak bekatul cenderung memiliki polaritas yang sama dengan etanol. Adapun nilai rendemen ekstrak bekatul dengan pelarut etil asetat dan $\mathrm{n}$ heksana masing-masing sebesar 7,282-9,180\% dan 7,125-7,815\%. Variasi lama ekstraksi tidak banyak berpengaruh terhadap hasil rendemen. Hal ini ditunjukkan dengan nilai rendemen yang tidak berbeda jauh.

Tabel 1. Rendemen EkstrakBekatul

\begin{tabular}{cc}
\hline Sampel & Rendemen (\%) \\
\hline E1-20 & 18,159 \\
E1-25 & 19,132 \\
E1-30 & 18,280 \\
E2-20 & 8,302 \\
E2-25 & 7,282 \\
E2-30 & 9,180 \\
E3-20 & 7,815 \\
E3-25 & 7,125 \\
E3-30 & 7,279 \\
\hline
\end{tabular}

\subsection{Uji Toksisitas terhadap Larva Udang}

Tingkat toksisitas ekstrak bekatul diukur menggunakan parameter $\mathrm{LC}_{50}$ (Lethal Concentration $50 \%$ ). $\mathrm{LC}_{50}$ merupakan nilai dosis dimana senyawa dapat membunuh $50 \%$ dari hewan uji. Proses kematian larva udang disebabkan oleh senyawa metabolit sekunder yang bersifat toksik. Masuknya metabolit sekunder dalam larva udang dapat mengganggu metabolisme tubuh [12]. Nilai LC 50 dari sembilan sampel ekstrak bekatul terangkum pada Tabel 2.

Tabel 2. Hasil Uji Toksisitas Menggunakan Metode BSLT

\begin{tabular}{cc}
\hline Sampel & LC $_{50}(\mathbf{p p m})$ \\
\hline E1-20 & 613,258 \\
E1-25 & 673,210 \\
E1-30 & 2217,255 \\
E2-20 & 1161,398 \\
E2-25 & 1170,774 \\
E2-30 & 701,532 \\
E3-20 & 592,901 \\
E3-25 & 617,425 \\
E3-30 & 695,198 \\
\hline
\end{tabular}

Berdasarkan hasil uji toksisitas pada Tabel 2, menunjukkan E3-20 (hasil ekstraksi menggunakan n-heksana selama 20 menit) memiliki nilai $\mathrm{LC}_{50}$ terendah. Semakin rendah nilai $\mathrm{LC}_{50}$ maka kemampuan ekstrak dalam membunuh larva udang semakin baik atau memiliki toksisitas tinggi [20]. Lama waktu ekstraksi juga mempengaruhi nilai LC ${ }_{50}$ dimana nilai $\mathrm{LC}_{50}$ ekstrak bekatul cenderung meningkat dengan bertambahnya lama waktu ekstraksi. Nilai toksisitas ekstrak bekatul dengan pelarut etanol meningkat seiring meningkatnya lama ekstraksi. Sedangkan pada pelarut etil asetat, semakin lama waktu ekstraksi, nilai $\mathrm{LC}_{50}$ ekstrak bekatul semakin kecil. Pada ekstrak bekatul dengan $\mathrm{n}$-heksana, nilai $\mathrm{LC}_{50}$ sampel relatif tidak berubah dengan peningkatan waktu ekstraksi, hal ini menandakan bahwa waktu ekstraksi tidak berpengaruh terhadap senyawa aktif. Berdasarkan lama ekstraksi, ekstrak bekatul dengan pelarut n-heksana menit 20 (E3-20) bersifat lebih toksik dengan nilai LC 50 sebesar 592,901 ppm. 


\subsection{Uji Kandungan Senyawa Aktif}

Hasil uji fitokimia pada ekstrak bekatul dengan pelarut etanol, etil asetat dan $n$-heksana menunjukkan semua ekstrak bekatul mengandung senyawa triterpenoid dan steroid (Tabel 3). Senyawa steroid ditandai dengan terbentuknya warna hijau kekuningan, sedangkan senyawa triterpenoid ditandai dengan terbentuknya cincin kecoklatan atau violet. Pada penelitian ini, sampel bekatul yang digunakan berasal dari beras putih varietas Pertiwi berasal dari Desa Tumpang, Malang. Penelitian lain juga menyebutkan bahwa ekstrak bekatul mengandung senyawa steroid dan triterpenoid [17]. Bekatul dari padi beras putih varietas Cempo Ireng (Desa Sayegan, Yogyakarta), Woja Laka (Kepanjen, Malang), Toraja (Bandar Lampung, Lampung) dan IR64 (Desa Minggiur, Yogyakarata) mengandung senyawa aktif fenol, flavonoid, terpenoid, dan steroid [21]. Kandungan senyawa aktif dalam bekatul bervariasi bergantung varietas dan daerah penanaman padi.

Tabel 3. Hasil Uji Fitokimia Ekstrak Bekatul

\begin{tabular}{ccccccc}
\hline Sampel & Alkaloid & Flavonoid & Steroid & Triterpenoid & Tanin & Saponin \\
\hline E1-20 & - & - & + & ++ & - & - \\
E1-25 & - & - & ++ & ++ & - & - \\
E1-30 & - & - & + & ++ & - & - \\
E2-20 & - & - & + & ++ & - & - \\
E2-25 & - & - & + & + & - & - \\
E2-30 & - & - & ++ & + & - & - \\
E3-20 & - & - & + & + & - & - \\
E3-25 & - & - & + & + & - & - \\
E3-30 & - & - & ++ & + & - & - \\
\hline Tanda "+" menunjukkan sampel mengandung metabolit sekunder dengan warna hasil uji lebih muda, tanda \\
"++" menunjukkan sampel mengandung metabolit sekunder dengan warna hasil uji lebih pekat, dan tanda "- \\
"menunjukkan sampel tidak mengandung metabolit sekunder.
\end{tabular}

\subsection{Pemisahan Senyawa Aktif dengan KLTA}

Pemisahan golongan senyawa aktif menggunakan KLTA dengan silika yang dilapiskan pada plat aluminium sebagai fasa diam dan campuran n-heksana:etil asetat (8:2) sebagai fasa gerak. Hasil pemisahan KLTA dibawah lampu UV pada panjang gelombang $366 \mathrm{~nm}$ ditunjukkan pada Gambar 1. Hasil pemisahan pada ekstrak n-heksana menunjukkan terbentuknya 5 noda dengan nilai $R_{f}$ yang berbeda $(0,0275-0,65)$ (Tabel 4). Perbedaan ini karena adanya perbedaan struktur dan distribusi senyawa aktif terhadap fasa gerak dan fasa diam. Senyawa yang memiliki nilai distribusi yang besar maka akan tertahan dalam fasa diam sehingga memiliki nilai $R_{f}$ yang kecil. Adapun senyawa yang memiliki nilai distribusi kecil akan terdistribusi dalam fasa gerak sehingga nilai $R_{f}$ senyawa tersebut besar.

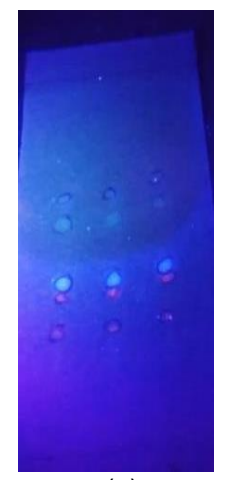

(a)

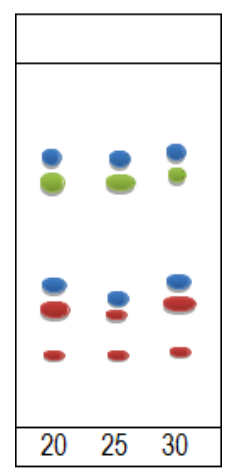

(b)

Gambar 1. (a) Noda pada plat, dan (b) llustrasi pola pemisahan

Perbedaan warna noda dikarenakan setiap senyawa memiliki panjang gelombang yang berbeda sehingga absorbansi juga berbeda. Pada panjang gelombang $366 \mathrm{~nm}$, adanya flavonoid ditandai dengan warna biru, steroid ditandai dengan warna hijau dan triterpenoid ditandai dengan warna merah. Pada uji fitokimia, golongan senyawa bersifat polar seperti flavonoid tidak tampak. Hal ini dikarenakan uji fitokimia merupakan tahapan awal untuk mengidentifikasi kandungan senyawa pada sampel sehingga diperlukan uji lanjut. 
Tabel 4. Hasil Identifikasi Ekstrak n-Heksana dengan Lampu UV 366 nm

\begin{tabular}{ccccc}
\hline Ekstrak & Jumlah Noda & $\boldsymbol{R}_{\boldsymbol{f}}$ & Warna & Dugaan Senyawa \\
\hline E3-20 & 5 & 0,275 & Merah & Triterpenoid \\
& 0,3375 & Merah & Triterpenoid \\
& 0,4 & Biru & Flavonoid \\
& & 0,55 & Hijau & Steroid \\
& & 0,6125 & Biru & Flavonoid \\
E3-25 & \multirow{2}{*}{5} & 0,275 & Merah & Triterpenoid \\
& & 0,35 & Merah & Triterpenoid \\
& & 0,3875 & Biru & Flavonoid \\
& & 0,55 & Hijau & Steroid \\
& & 0,6125 & Biru & Flavonoid \\
E3-30 & & 0,2875 & Merah & Triterpenoid \\
& \multirow{2}{*}{5} & 0,375 & Merah & Triterpenoid \\
& & 0,4125 & Biru & Flavonoid \\
& & 0,5875 & Hijau & Steroid \\
& & 0,65 & Biru & Flavonoid \\
\hline
\end{tabular}

\subsection{Pemisahan Senyawa Aktif dengan KLTP}

KLTP dilakukan untuk mendapatkan isolat senyawa aktif pada plat berukuran $10 \times 20 \mathrm{~cm}$. Elusi dilakukan menggunakan eluen etil asetat:n-heksana (2:8). Hasil pemisahan KLTP terhadap ekstrak n-heksana bekatul ditunjukkan pada Gambar 2, 3, dan 4. Pemisahan KLTP pada ekstrak n-heksana pada lama ekstraksi 20 menit (E320) menghasilkan 6 noda, sedangkan ekstrak n-heksana pada lama ekstraksi 25 menit (E3-25) dan 30 menit (E3-30) menghasilkan 7 noda (Tabel 5).

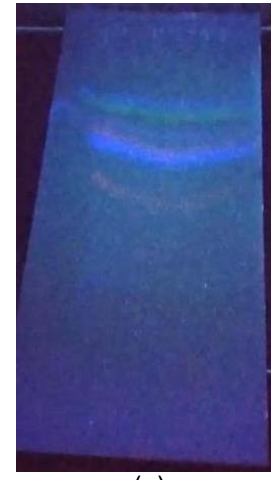

(a)

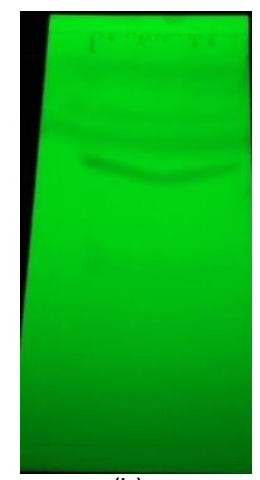

(b)

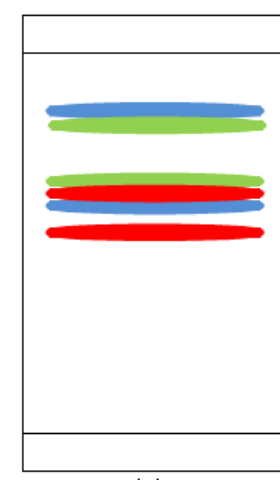

(c)

Gambar 2. Pemisahan sampel E3-20 pada (a) 366 nm, (b) 254 nm dan (c) llustrasi pola pemisahan

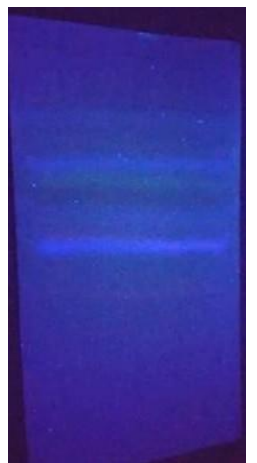

(a)

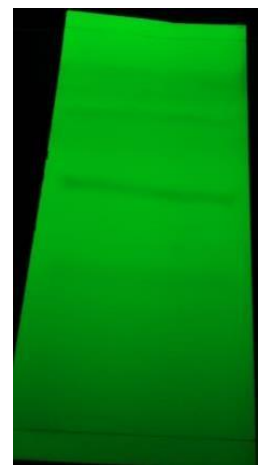

(b)

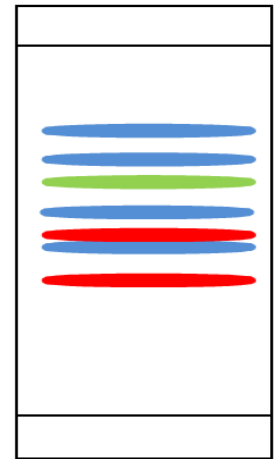

(c)

Gambar 3. Pemisahan sampel E3-25 pada (a) 366 nm, (b) 254 nm dan (c) llustrasi pola pemisahan 


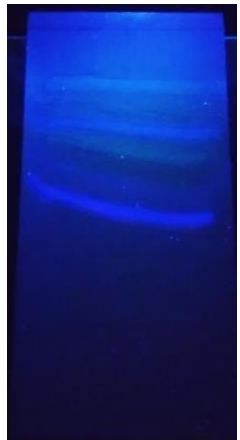

(a)

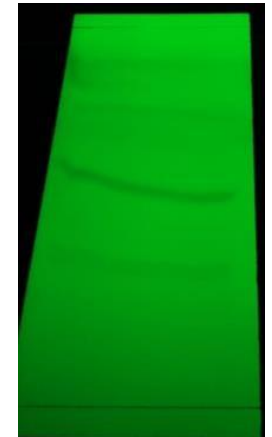

(b)

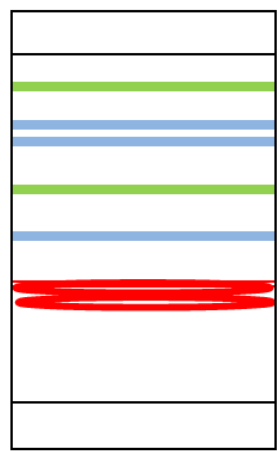

(c)

Gambar 4. Pemisahan sampel E3-30 pada (a) $366 \mathrm{~nm}$, (b) $254 \mathrm{~nm}$ dan (c) ilustrasi pola pemisahan

Tabel 5. Hasil Pemisahan KLTP Ekstrak Bekatul dengan n-Heksana

\begin{tabular}{|c|c|c|c|}
\hline Sampel & $R_{f}$ & Warna Noda & Dugaan Senyawa \\
\hline \multirow[t]{6}{*}{ E3-20 } & 0,5444 & Merah & Triterpenoid \\
\hline & 0,6222 & Biru & Flavonoid \\
\hline & 0,6778 & Merah & Triterpenoid \\
\hline & 0,7333 & Hijau & Steroid \\
\hline & 0,8333 & Hijau & Steroid \\
\hline & 0,9243 & Biru & Flavonoid \\
\hline \multirow[t]{7}{*}{ E3-25 } & 0,3167 & Merah & Triterpenoid \\
\hline & 0,5278 & Hijau & Steroid \\
\hline & 0,6056 & Merah & Triterpenoid \\
\hline & 0,6889 & Hijau & Steroid \\
\hline & 0,7333 & Hijau & Steroid \\
\hline & 0,8056 & Biru & Flavonoid \\
\hline & 0,85 & Biru & Flavonoid \\
\hline \multirow[t]{7}{*}{ E3-30 } & 0,5444 & Merah & Triterpenoid \\
\hline & 0,4778 & Merah & Triterpenoid \\
\hline & 0,6444 & Biru & Flavonoid \\
\hline & 0,7056 & Hijau & Steroid \\
\hline & 0,7556 & Biru & Flavonoid \\
\hline & 0,8278 & Biru & Flavonoid \\
\hline & 0,8722 & Hijau & Steroid \\
\hline
\end{tabular}

Berdasarkan Tabel 5, ekstrak n-heksana pada sampel bekatul mengandung senyawa triterpenoid, steroid dan flavonoid. Pelarut n-heksana yang bersifat non-polar mampu mengekstrak senyawa-senyawa yang bersifat non-polar seperti sterol dan terpenoid [18]. Oleh karena itu, pada pemisahan KLTP ini pelarut n-heksana munculnya senyawa steroid ditandai dengan warna hijau dan merah, sedangkan triterpenoid berwarna merah. Steroid dapat dideteksi dengan sinar UV berupa warna hijau dan flavonoid berwarna biru [19].

\section{Kesimpulan}

Ekstrak n-heksana bekatul dengan lama ekstraksi 20 menit memberikan nilai toksisitas terbaik dengan $\mathrm{LC}_{50}$ sebesar 592,901 ppm. Ekstrak n-heksana bekatul setelah dilakukan pemisahan dengan KLT mengandung senyawa aktif golongan flavonoid, steroid dan triterpenoid.

\section{Daftar Pustaka}

[1] Balai Besar Penelitian dan Pengembangan Pascapenen Pertanian, "Mengolah Dedak Menjadi Minyak (Rice Bran Oil)," Warta Penelitian dan Pengembangan Pertanian, vol. 29, no.4, pp. 8-10, 2007.

[2] M.-H Chen \& C. J. Bargmen, "A Rapid Procedure for Analysing Rice Bran Tocopherol, Tocotrienol, and y-Oryzanol Contents," Journal of Food Composition and Analysis, vol. 18, no. 2-3, pp. 139-151, 2005. 
[3] Faizah, F. Kusnandar, \& S. Nurjanah, "Senyawa Fenolik, Oryzanol, dan Aktivitas Antioksidan Bekatul yang Difermentasi dengan Rhizopus oryzae," Jurnal Teknologi dan Industri Pangan, vol. 31, no.1, pp. 86-94, 2020.

[4] A. J. Henderson, C. A. Ollila, A. Kumar, E. C. Borresen, K. Raina, R. Agarwal, \& E. P. Ryan, "Chemopreventive Properties of Dietary Rice Bran: Current Status and Future Prospects," Advances in Nutrition, vol. 3, no. 5, pp. 643653, 2012.

[5] E. M. Moko, H. Purnomo, J. Kusnandi, \& F. G. ljong, "Phytochemical Content and Antioxidant Properties of Colored and Non Colored Varieties of Rice Bran from Minahasa, North Sulawesi, Indonesia," International Food Research Journal, vol. 21, no. 3, pp. 1053-1059, 2014.

[6] M. N. Abubacker \& T. Deepalakshmi, "In Vitro Antifungal Potentials of Bioactive Compound Methyl Ester of Hexadecanoic Acid Isolated from Annona muricata Linn. Leaves," Biosciences Biotechnology Research Asia, vol. 10, no. 2, pp. 879-884, 2013.

[7] I. W. R. Widarta, K. A. Nocianitri, \& L. P. I. P. Sari, "Ekstraksi Komponen Bioaktif Bekatul Beras Lokal dengan Beberapa Jenis Pelarut," Jurnal Aplikasi Teknologi Pangan, vol. 2, no. 2, pp. 75-79, 2013.

[8] M. Iqbal, "Uji Aktivitas dan Identifikasi Senyawa Antioksidan dari Ekstrak Minyak Bekatul Beras Ketan Hitam (Oryza sativa Glutinosa)," Skripsi, Universitas Islam Negeri Maulana Malik Ibrahim, Malang, 2016.

[9] I. G. A. D. P. Dewi, "Kajian Rasio Bahan dengan Pelarut dan Waktu Ekstraksi terhadap Karakteristik Minyak Bekatul Beras Merah dengan Metode Ultrasonik," Skripsi, Universitas Udayana, Bali, 2016.

[10] P. Rana, S. Vadhera, \& G. Soni, "In vivo Antioxidant Potential of Rice Bran Oil (RBO) in Albino Rats," Indian Journal of Physiology and Pharmacology, vol. 48, no. 4, pp. 428-436, 2004.

[11] A. Ghasemzadeh, H. Z. E. Jaafar, A. S. Juraimi, \& A. T. Meigooni, "Comparative Evaluation of Different Extraction Techniques and Solvents for the Assay Phytochemicals and Antioxidant Activity of Hashemi Rice Bran," Molecules Journal, vol. 20, pp. 10822-10838, 2015.

[12] B. N. Meyer, N. R. Ferrigni, J. E. Putnam, L. B. Jacobsen, D. E. Nichols, \& J. L. McLaughlin, "Brine Shrimp: A Convenient General Bioassay for Active Plant Constituents," Planta Medica, vol. 45, no. 5, pp. 31-34, 1982.

[13] AOAC, Official Methods of Analysis, 18 th Ed. Arlington: Association of Official Analytical Chemists, 2005.

[14] R. Hendryani, M. Lutfi, \& L. C. Hawa, "Ekstraksi Antioksidan Daun Sirih Merah Kering (Piper crotatum) dengan Metode Pra-Perlakuan Ultrasonic Assisted Extraction (Kajian Perbandingan Jenis Pelarut dan Lama Ekstraksi)," Jurnal Bioproses Komoditas Tropis, vol. 3, no. 2, pp. 33-38, 2015.

[15] N. Inayah, R. Ningsih, \& T. K. Adi, "Uji Toksisitas dan Identifikasi Awal Golongan Senyawa Aktif Ekstrak Etanol dan nHeksana Teripang Pasir (Holothuria scabra) Kering Pantai Kenjeran Surabaya," ALCHEMY, vol.2, no. 1, pp. 92-100, 2012.

[16] J. B. Harborne, Metode Fitokimia: Penuntun Cara Modern Menganalisis Tumbuhan. Bandung: Institut Teknologi Bandung, 1987.

[17] S. T. Ulfa, "Identifikasi dan Uji Aktivitas Senyawa Antioksidan dan Bekatul dengan Menggunakan Variasi Pelarut," Skripsi, Universitas Islam Negeri Maulana Malik Ibrahim, Malang, 2016.

[18] Departemen Kesehatan Republik Indonesia, Farmakope Herbal Indonesia. Jakarta: Departemen Kesehatan Republik Indonesia, 2008.

[19] L. K. Dewi, "Kajian Ekstrak Umbi Gadung (Dioscorea hispida), Biji Rerak (Sapindus rarak) dan Biji Sirsak (Annona muricata L.) sebagai Bahan Pengawet Alami Kayu," Skripsi, Institut Pertanian Bogor, Bogor, 2007.

[20] J. L. McLaughlin, C. J. Chang, \& D. L. Smith, "Bench - Top Bioassays for the Discovery of Bioactive Natural Products an Update" in Studies in Natural Products Chemistry. Amsterdam: Elsevier, 1991.

[21] R. M. Rukmana, N. P. Soesilo, Rumiyati, \& R. Pratiwi, "The Effect of Ethanolic Extract of Black and White Rice Bran (Oryza sativa L.) on Cancer Cells, "Indonesian Journal of Biotechnology, vol. 21, no.1, pp. 63-69, 2016. 